\title{
A Case of Primary Dural Lymphoma: Diffuse Large B-Cell Type
}

\section{Bir Primer Dural Lenfoma Olgusu: Difü: Büyük B-Hücre Tipi}

\author{
Won Hee $\mathrm{LEE}^{1}$, Bomi KIM ${ }^{2}$, Moo Seong KIM ${ }^{1}$ \\ ${ }^{1}$ Inje University, School of Medicine, Busan Paik Hospital, Department of Neurosurgery, Busan, Korea \\ ${ }_{2}^{2}$ Inje University, School of Medicine, Busan Paik Hospital, Department of Pathology, Busan, Korea
}

Corresponding Author: Won Hee LEE / E-mail: ywh9868@gmail.com

\begin{abstract}
Primary leptomeningeal lymphoma is very rare disease that is a subtype of primary central nervous system (CNS) lymphoma. Primary dural lymphoma is a subentity of primary leptomeningeal lymphoma and arises from the dura mater without systemic disease. A 47-year-old woman presented with an indolent mass in the right frontal region. The patient's physical examination demonstrated no focal neurological abnormality. Magnetic resonance imaging (MRI) study revealed a mass lesion in the right frontal region. The patient underwent a right frontal craniectomy and removal of tumor. Histological diagnosis was diffuse large B-cell lymphoma (DLBCL). The patient received chemotherapy with rituximab, cyclophosphamide, adriamycin, vincristine, and prednisolone (R-CHOP protocol) every 3 weeks for six cycles. The patient was discharged without neurological deficit and no evidence of tumor recurrence. There was no systemic dissemination of disease 72 months after the surgery. Until the optimal standard management protocol is established, the treatment should be with an individualized multidisciplinary approach and continued follow-up and clinical surveillance are recommended for every patient.
\end{abstract}

KEYWORDS: Lymphoma, Large B-cell, Diffuse, R-CHOP protocol

\section{Öz}

Primer leptomeningeal lenfoma, primer merkez sinir sistemi (MSS) lenfomasının bir alt tipi olan çok nadir bir hastalıktır. Primer dural lenfoma, primer leptomeningeal lenfomanın bir alt tipidir ve sistemik hastalık olmadan dura materden gelişir. 47 yaşında bir kadın, sağ frontal bölgede ağrısız bir kitleyle başvurdu. Hastanın fiziksel incelemesi herhangi bir fokal nörolojik anormallik göstermedi. Manyetik rezonans görüntüleme (MRG) incelemesi sağ frontal bölgede bir kitle gösterdi. Hastaya sağ frontal kraniyektomi ve tümör eksizyonu işlemi yapıldı. Histolojik tanı difüz büyük B-hücreli lenfomaydı (DLBCL). Hastaya rituksimab, siklofosfamid, adriamisin, vinkristin, ve prednizolon (R-CHOP protokolü) ile altı kür boyunca 3 haftada bir kemoterapi verildi. Hasta herhangi bir nörolojik defisit ve tümör nüksü bulgusu olmadan taburcu edildi. Cerrahiden 72 ay sonra hastalığın sistemik yayılması yoktu. Optimum standart takip protokolü belirleninceye kadar tedavi multidisipliner bir yaklaşımla hastaya özelleştirilmelidir ve her hasta için devamlı takip ve klinik gözetim önerilir.

ANAHTAR SÖZCÜKLER: Lenfoma, Büyük B-hücreli, Difüz, R-CHOP protokolü

\section{INTRODUCTION}

Primary leptomeningeal lymphoma is very rare disease that is a subtype of primary CNS lymphoma. Primary CNS lymphoma is an extranodal non-Hodgkin's lymphoma $(1,5)$ and accounts for less than $1 \%$ of all non-Hodgkin's lymphomas (12). Primary leptomeningeal lymphoma represents less than $0.1 \%$ of all non-Hodgkin's lymphomas (15). It usually presents with nonspecific neurological symptoms and signs such as headache, meningeal signs, and cranial nerve involvement (11).

Primary dural lymphoma is a subentity of primary leptomeningeal lymphoma and arises from the dura mater with no systemic disease $(2,7,20)$. There is no standard treatment for primary dural lymphoma due to the paucity of cases (5).

Herein, we report a case of primary dural lymphoma with a favorable clinical course after surgery and chemotherapy.

\section{CASE REPORT}

A 47-year-old woman with no previous medical or surgical history presented to another hospital with an indolent mass in the right frontal region. She was referred to our hospital for surgical treatment after a brain MRI was performed. The patient's physical examination demonstrated no focal neurological abnormality other than a palpable right frontal mass involving the scalp. MRI study revealed mass lesion in the right frontal region which appeared hypointense on $\mathrm{T}_{1}$ weighted imaging, hyperintense on $\mathrm{T}_{2}$-weighted imaging, and homogeneously enhanced after administration of gadolinium (Figure 1A, B). The mass measured $4 \mathrm{~cm}$ (lateral) x $3 \mathrm{~cm}$ (anteroposterior) x $1.5 \mathrm{~cm}$ (vertical) and invaded the skull and dura on MR imaging.

Under general anesthesia, the patient underwent a right frontal craniectomy. The tumor was gray, firm, relatively hypovascular and severely infiltrated the skull and dura. The tumor was excised en-bloc and the infiltrated bone flap and dura were removed. The dura was closed with a galeaperiosteal flap, and bone cement was molded to the defect shape used for cranioplasty(Figure 2A-D). 
A lymphoma was suspected on intraoperative frozen biopsy. Chest and abdominal CT, bone scintigraphy and bone marrow biopsy were performed to find occult systemic disease but no other systemic lymphoma was detected.

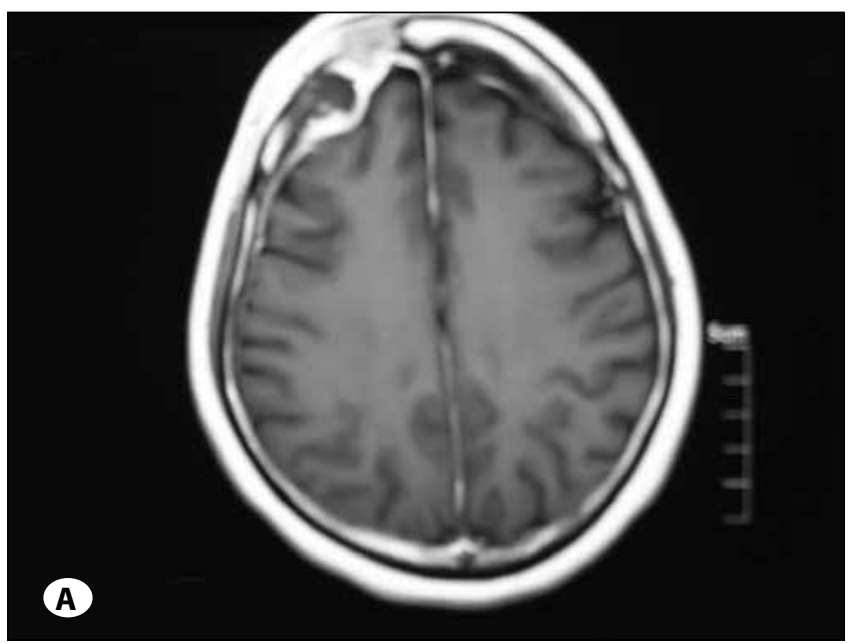

Hematoxylin and eosin stain revealed the cellular solid mass lesion that was attached to the dura and infiltrated the cranial bone marrow spaces with extensive necrosis, at low power. The large lymphoid tumor cells showed severe cellular atypism such as high nuclear/cytoplasmic ratio (N/C ratio),

Figure 1: A) Axial and B) Sagittal $T_{1}$ weighted MR image with gadolinium contrast demonstrates a homogeneously-enhanced mass lesion in the right frontal area that has invaded the dura and skull.
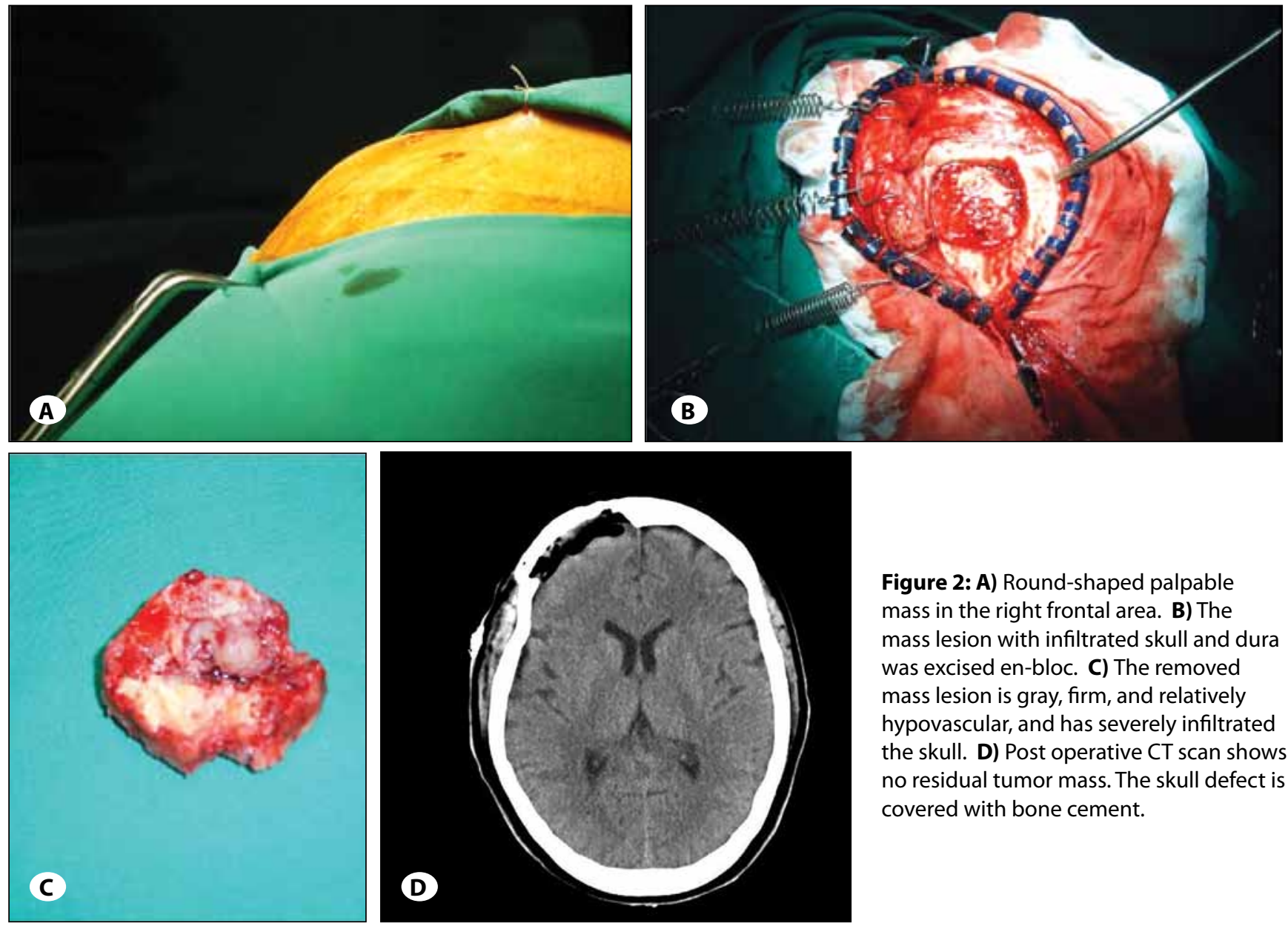

Figure 2: A) Round-shaped palpable mass in the right frontal area. B) The mass lesion with infiltrated skull and dura was excised en-bloc. C) The removed mass lesion is gray, firm, and relatively hypovascular, and has severely infiltrated the skull. D) Post operative CT scan shows no residual tumor mass. The skull defect is covered with bone cement. 

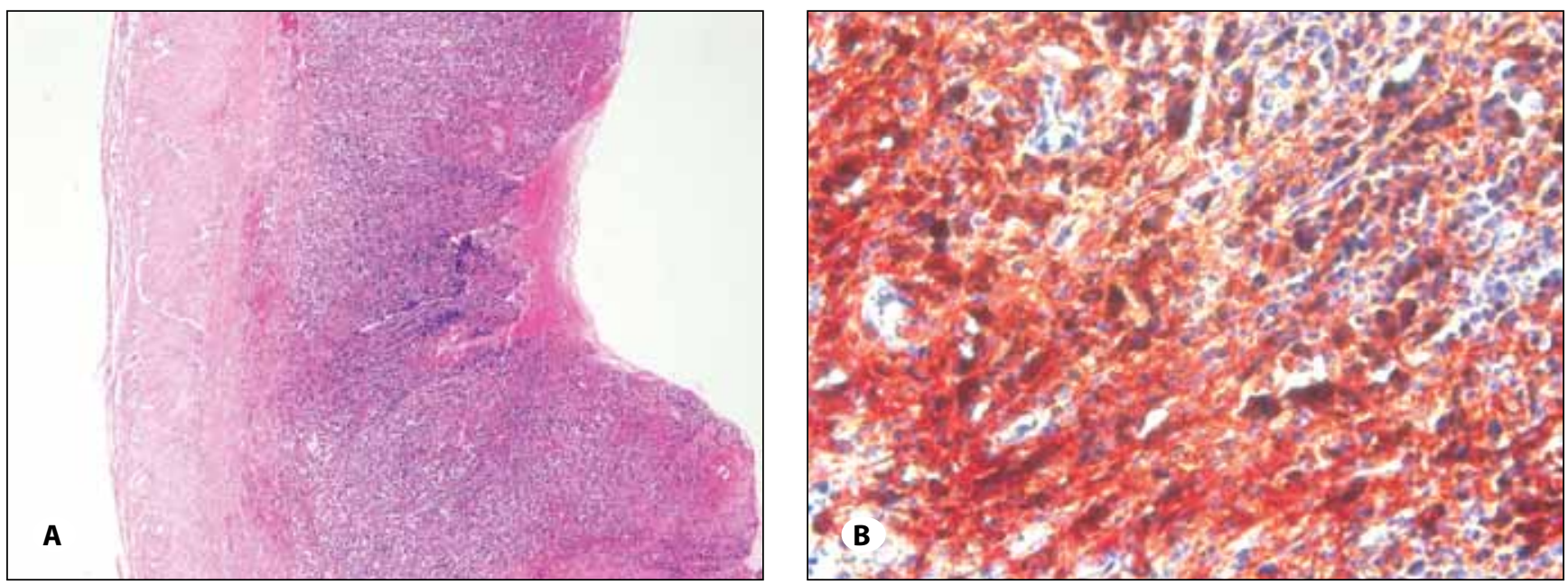

Figure 3: A) The low-power microscopic examination shows that the cellular solid mass lesion is attached to the dura (hematoxylin and eosin, x40). B) The CD20 immunohistochemical stain was positive in large atypical lymphoid cells (hematoxylin and eosin, x400).

prominent nucleoli, irregular nuclear membrane and frequent mitoses. They reacted with the CD20 antibody, which is one a B cell marker (Figure 3A, B). Cytokeratin, vimentin, CD3, $C D 45 R O$, and CD5 were all negative on immunohistochemical studies. The pathology diagnosis was diffuse large B cell lymphoma of the dura. After the histological diagnosis was confirmed, the patient received chemotherapy with rituximab, cyclophosphamide, adriamycin, vincristine, and prednisolone (R-CHOP) every 3 weeks for six cycles. She was discharged without neurological deficit and no evidence of tumor recurrence. There was no systemic dissemination of disease 72 months after the surgery.

\section{DISCUSSION}

The incidence of primary dural lymphoma is unknown but it is a very rare disease. The incidence of this tumor varies from $0.6 \%$ to $3 \%$ of all brain tumors $(7,20,21)$. Iwamoto et al. reported an incidence $2.4 \%$ of 355 patients with primary CNS lymphomas in their institution at 2006 (6). Brain parenchyma primary CNS lymphomas occur more often in males, but primary dural lymphomas occur more frequently in females. The female/male ratio was from 4:1 to 3:1 (5) while for the malignant B-cell type it was reported as 23:2 (21). Primary CNS lymphomas were associated with immunosuppression, unlike primary dural lymphomas that have no clear association with immunocompromised conditions (14).

The pathogenesis of primary dural lymphoma is unclear because the dura lacks any lymphoid tissue (5). Many hypotheses have been formulated including the role of a chronic inflammatory process, chronic infection, autoimmune diseases like scleroderma, Graves disease, Sjögren disease, and the meningoepithelial component $(5,15)$.

Clinical manifestations are usually dependent on the location of the tumor. The most common symptoms are headache, seizure and meningeal signs. Cranial nerve involvement symptoms like visual and hearing disturbance, and diplopia can also be present $(6,10)$. Goetz et al. reported a patient with unusual symptoms who had headaches and acute hemiparesis mimicking an acute subdural hematoma (4). Radicular pain and paraparesis are the most common presenting symptoms in the case of spinal primary dural lymphomas (15).

Magnetic resonance imaging reveals single or multiple dural-based extraaxial masses that diffusely enhance after administration of gadolinium (6). The most common site is the cerebral convexities, but the falx, tentorium, sellar/ suprasellar regions and intraventricular and spine lesions can also be involved $(13,19)$. En plaque thickening of meninges, dural tail sign, underlying parenchymal vasogenic edema, early invasion of the underlying brain, calvarial hyperostosis, and bone erosion have been demonstrated with magnetic resonance imaging (5).

The differential diagnosis includes meningioma, dural metastasis, solitary fibrous tumors, gliosarcomas, hemangiopericytomas, and inflammatory pseudotumors (9). Meningioma is the first to be considered in the differential diagnosis. Both tumors share many radiographic and clinical features, including a higher incidence in women, and similar age of onset and magnetic resonance imaging findings. The presence of vasogenic edema and parenchymal brain invasion with a fuzzy tumor brain interface favors a diagnosis of primary dural lymphomas (15).

The most frequent histopathological diagnosis of primary dural lymphoma is marginal zone lymphoma (MZL) (5). Highgrade non-Hodgkin lymphoma, low-grade follicular lymphoma, and Hodgkin disease have also been rarely reported (5, 8,13 ). The pathological features of MZLs arising in the dura are similar to MZLs at other extranodal sites (22). Our case was $\mathrm{DLBCL}$, which is more common in other types of primary CNS lymphomas (5). We briefly compared the case with primary CNS lymphomas and primary dural lymphomas (Table I).

Primary dural lymphoma is a very rare disease and there is no standard treatment. Extranodal disease limited to a 
Table I: Comparison with CNS Lymphomas and Primary Dural Lymphomas

\begin{tabular}{l|c|c} 
& Primary CNS lymphoma & Primary Dural lymphoma \\
\hline Site & Brain parenchyma & Leptomeningeal space \\
Common histologic type & DLBCL & MZL \\
Sex & Male $>$ & $\mathrm{F}: \mathrm{M}=4: 1 \sim 3: 1$ \\
Association between immunosuppresion & Yes & No
\end{tabular}

CNS: central nervous system, DLBCL: diffuse large B-cell lymphoma, MZL: marginal zone lymphoma.

single site responds favorably to surgery or focal radiation $(16,18,22)$. Complete resection can be technically difficult due to multiple lesions, infiltrative behavior, or en plaque presentation. Adjuvant treatment is necessary in most cases. No additional treatment is needed if complete resection is achieved $(5,15)$. Radiotherapy is effective treatment in MZLs. Iwamoto et. al. reported that a radiation dose as low as 20 Gy provides excellent results and minimizes the risk of late neurotoxicity (6). Systemic adjuvant chemotherapy is also available. High-dose methotrexate or $\mathrm{R}-\mathrm{CHOP}$ regimen is effective for parenchymal CNS lymphomas, but the effect is unclear in primary dural lymphomas. There is no guideline in terms of the standard regimen to be used so the decision should be made individually (15). If the leptomeningeal involvement is checked, intrathecal chemotherapy or wholebrain radiotherapy is required (5).

A primary dural lymphoma is more indolent and has a better prognosis than parenchymal primary CNS lymphoma or systemic lymphoma with CNS metastasis. The 5-year overall survival rate was greater than $86 \%$ in MZLs (17). Diffuse large B-cell type lymphoma also has a relatively benign prognosis (21). In comparison, patients with non-Hodgkin lymphomas in the CNS have survived for 12 to 18 months (3), and only $8 \%$ have survived longer than 3 years (14). Systemic recurrence can occur several years after the initial diagnosis of primary dural lymphomas and continued follow-up and clinical surveillance are recommended for every patient (5).

\section{CONCLUSION}

Primary dural lymphoma is very rare disease so that there is no standard treatment. It responds well to local treatments such as surgery or radiation therapy and has a favorable clinical outcome in most patients $(17,18,22)$. Systemic recurrence can occur several years after the diagnosis. Until the optimal standard management protocol is established, the treatment should be with an individualized multidisciplinary approach and continued follow-up and clinical surveillance are recommended for every patient.

\section{REFERENCES}

1. Abrey LE, Yahalom J, DeAngelis LM: Treatment for primary CNS lymphoma: The next step. J Clin Oncol 18: 3144-3150, 2000
2. Benouaich A, Delord JP, Danjou M, Richaud J, Urocoste $E_{4}$ Soum F, Aziza R: Primary dural lymphoma: A report of two cases with review of the literature. Rev Neurol (Paris) 159: 652-658, 2003

3. Freudenstein D, Bornemann A, Ernemann U, Boldt R, Duffner F: Intracranial malignant B-cell lymphoma of the dura. Clin Neuropathol 19: 34-37, 2000

4. Goetz P, Lafuente J, Revesz T, Galloway M, Dogan A, Kitchen $\mathrm{N}$ : Primary low-grade B-cell lymphoma of mucosa-associated lymphoid tissue of the dura mimicking the presentation of an acute subdural hematoma. J Neurosurg 96: 611-614, 2002

5. Iwamoto FM, Abrey LE: Primary dural lymphomas: A review. Neurosurg Focus 21 (5): E5, 2006

6. Iwamoto FM, DeAngelis LM, Abrey LE: Primary dural lymphomas: A clinicopathologic study of treatment and outcome in eight patients. Neurology 66: 1763-1765, 2006

7. Jellinger K, Radaskiewicz T, Slowik F: Primary malignant lymphomas of the central nervous system in man. Acta Neuropathol Suppl 6: 95-102, 1975

8. Johnson MD, Kinney MC, Scheithauer BW, Briley RJ, Hamilton $\mathrm{K}$, McPherson WF, Barton Jr. JH: Primary intracerebral hodgkin's disease mimicking meningioma: Case report. Neurosurgery 47: 454-457, 2000

9. Johnson MD, Powell SZ, Boyer PJ, Weil RJ, Moots PL: Dural lesions mimicking meningiomas. Hum Pathol 33: 1211-1226, 2002

10. Kim HJ, Ha CK, Jeon BS: Primary leptomeningeal lymphoma with long-term survival: A case report. J Neurooncol 48: 47-49, 2000

11. Lachance $D, O^{\prime}$ Neill B, Macdonald D, Jaeckle K, Witzig T, Li CY, Posner JB: Primary leptomeningeal lymphoma report of 9 cases, diagnosis with immunocytochemical analysis, and review of the literature. Neurology 41: 95-100, 1991

12. Maher EA, Fine HA: Primary CNS lymphoma. Semin Oncol 26: 346-356, 1999

13. Miranda RN, Glantz LK, Myint MA, Levy $N$, Jackson $C L$, Rhodes CH, Glantz MJ, Medeiros LJ: Stage IE non-hodgkin's lymphoma involving the dura: A clinicopathologic study of five cases. Arch Pathol Lab Med 120: 254-260, 1996

14. Murray K, Kun L, Cox J: Primary malignant lymphoma of the central nervous system. J Neurosurg 65: 600-607, 1986

15. Said R, Rizk S, Dai Q: Clinical challenges of primary diffuse large B-cell lymphoma of the dura: Case report and literature review. ISRN Hematol 2011:945212, 2011 
16. Thieblemont $C$, Bastion $Y$, Berger F, Rieux C, Salles G, Dumontet C, Felman P, Coiffier B: Mucosa-associated lymphoid tissue gastrointestinal and nongastrointestinal lymphoma behavior: Analysis of 108 patients. J Clin Oncol 15: 1624-1630, 1997

17. Thieblemont $C$, Berger F, Dumontet $C$, Moullet I, Bouafia F, Felman P, Salles G, Coiffier B: Mucosa-associated lymphoid tissue lymphoma is a disseminated disease in one third of 158 patients analyzed. Blood 95: 802-806, 2000

18. Tsang RW, Gospodarowicz MK, Pintilie M, Wells W, Hodgson DC, Sun A, Crump M, Patterson BJ: Localized mucosaassociated lymphoid tissue lymphoma treated with radiation therapy has excellent clinical outcome. J Clin Oncol 21: 4157-4164, 2003
19. Tu $P$, Giannini $C$, Judkins $A R$, Schwalb JM, Burack $R$, O'Neill BP, Yachnis AT, Burger PC, Scheithauer BW, Perry A: Clinicopathologic and genetic profile of intracranial marginal zone lymphoma: A primary low-grade CNS lymphoma that mimics meningioma. J Clin Oncol 23: 5718-5727, 2005

20. Woodman R, Shin K, Pineo G: Primary non-hodgkin's lymphoma of the brain. A review. Medicine 64: 425-430, 1985

21. Yamada SM, Ikawa N, Toyonaga S, Nakabayashi H, Chang Park K, Shimizu K: Primary malignant B-cell-type dural lymphoma: Case report. Surg Neurol 66: 539-543, 2006

22. Zucca E, Conconi A, Pedrinis E, Cortelazzo S, Motta T, Gospodarowicz MK, Patterson BJ, Ferreri AJM, Ponzoni M, Devizzi L: Nongastric marginal zone B-cell lymphoma of mucosa-associated lymphoid tissue. Blood 101: 2489-2495, 2003 